\title{
MODERN METHODS FOR THE VALORISATION OF PROTECTED AREAS IN IASTI COUNTY. THEIR MONITORING AND MANAGEMENT WITH GIS TECHNOLOGY
}

DOI: https://doi.org/10.18509/AGB.2021.09

UDC: 004.8/.9:528.9]:502.1(498)

\section{Cristina Carmen Stingu (Palici) ${ }^{1}$, Valentin Nedeff ${ }^{1}$, Ion Sandu ${ }^{2,3}$, Petronela Spiridon-Ursu², Silviu Octavian Gurlui ${ }^{4}$, Ioan Gabriel Sandu ${ }^{3,5}$, Mihaela Orlanda Antonovici (Munteanu) ${ }^{6}$, Viorica Vasilache ${ }^{7}$}

\author{
${ }^{I}$ Vasile Alecsandri University of Bacau, Department of Environmental \\ Engineering and Mechanical Engineering, Bacau, Romania \\ ${ }^{2}$ Alexandru Ioan Cuza University, ARHEOINVEST Interdisciplinary Platform, \\ Institute of Interdisciplinary Research, Iasi, Romania \\ ${ }^{3}$ Romanian Invention Forum, Iasi, Romania \\ ${ }^{4}$ Alexandru Ioan Cuza University, Faculty of Physics, Iaşi, Romania \\ ${ }^{5}$ Gheorghe Asachi Technical University of Iasi, Faculty of \\ Material Sciences and Engineering,Iasi, Romania \\ ${ }^{6}$ Alexandru Ioan Cuza University, Faculty of Geography and Geology, \\ Geoscience Doctoral School, Environmental Science Field, Iasi, Romania \\ ${ }^{7}$ Alexandru Ioan Cuza University of Iasi, Institute of Interdisciplinary \\ Research-Field Science, Iasi, Romania
}

corresponding author: cristina.7422@yahoo.com

\begin{abstract}
The paper presents a series of methods and techniques of investigation used in the valorisation of the special avifaunistic protection areas (SPA), which also integrate historical monuments, included in the list of sites of community importance (SCI) belonging to the Natura 2000 ecological network in Iasi county. One of the analysed aspects consists in monitoring the evolution of their conservation status, which calls for new technological discoveries regarding the instrumental analysis techniques and current methodological systems of processing / operation. The analyses used are those based on the Geographic Information System (GIS), which allow the geographical and cartographic representation of the characteristics contained in the relational databases, making possible the visual representation of the distribution of the natural assets and of the historical monuments in the study areas. The results of these analyses have a special impact on tourism and the development of disadvantaged areas, managing to identify the weaknesses induced by pollution and the anthropic factor.
\end{abstract}

Keywords: protected areas; biodiversity; free goods; historical monuments; sustainable use of resources; deterioration and degradation; pollution; the anthropic factor.

\section{INTRODUCTION}

The soil is a natural body dependent on the parental material and the pedogenetic processes to which it was exposed. With regard to soil properties (physical, chemical and biological), they have dynamic variability, both vertically and horizontally. In order to know and understand the effects of land use types and their management it is necessary to monitor the variation of soil properties. Over time, studies on the variability of soil properties have analyzed several factors such as: land slope, crop types, but also land use [1]. Soil properties are very important characteristics, especially when used for agronomic purposes. The land use in an area must take into account the compatibility between physical - chemical, bioclimatic characteristics and crop types [2]. In practice, especially in the case of individual farmers or small farms, the use of land is not always correlated with the soil type, the decisions depending on the level of education and experience of the land owners. However, the efficiency with which land use systems can be optimized will be 
based on soil properties that must correspond to the requirements of the crop type.

The type of land use, soil management practices influence soil nutrients and soil processes, such as erosion, oxidation, mineralization and runoff $[3,4]$, the transport and redistribution circuits of nutrients being modified. In fallow lands, the type of vegetative cover represents a factor that influences the organic matter content of the soil, which leads to the compulsory determination of soil characteristics [3]. The data regarding the physical and chemical properties of the soil are of particular importance in the planning and management of spatial variations of the soil, saving both time and

\section{MATERIAL AND METHODS}

International Union for Conservation of Nature (IUCN2) [1, 2, 3], defines the protected area as: "a clearly defined geographical area, recognized, designated and administered on the basis of legal acts or by other efficient means, in order to achieve the long-term nature conservation, as well as the environmental services and of the associated cultural values". In the case of our country, according to the Emergency Ordinance no. 57/2007 [4], which refers to the regime of the protected natural areas, the conservation of natural habitats, the flora and fauna, gives a clear definition for the protected natural area.

It is known that protected areas, through a policy of promoting sustainability, keep the genetic inventory of all living organisms, so that major imbalances do not occur between the components of a macrosystem, in this case biocenosis and implicitly related to the anthropic factor. Everything that is determined by the biotic environment in a biotope can be preserved, without human destructive intervention through anthropic, random and unlimited actions, with a purpose not well defined in its development and evolution.

The accession of Romania to the European Union, from the beginning, imposed a special responsibility of the decision-makers at national level with regard to the assets of the cultural heritage and those of the nature, part integrated in the European heritage. In this context, we can speak of a number of lucrative areas, beyond its preservation, special policies of valorization, promotion, creation and affirmation of a nation or country. Thus, in the new geopolitical context, national strategies are closely linked to policies formulated at European level, they are not isolated from economic or social ones [5].

Regarding the conservation of these heritage systems, a special attention is paid to the scientific investigation activities with multiple implications, first of all the evolution of the effects of financial resources, directly influencing the proper management of soil and crops, as well as the efficiency of soil research [5]. Inadequate soil management can lead to rapid deterioration of important land areas, often becoming a major threat to rural livelihoods in many developing and developed countries. Rarely, the consequences of changes in the land use on the soil are difficult to highlight, which leads to the delay of the initiation of ameliorative measures by the administrators of the respective lands.

The aim of this study was to analyse the effect of land-use on physicochemical soil properties for different types of culture.].

deterioration of the physical state of the structuralfunctional elements and of degradation of the chemical nature of the components, in correlation with the impact of the factors. endogenous and exogenous (especially anthropic activities, controlled or not), then elaboration of plans of reconformation (restoration, protection and maintenance/control/monitoring) and those of valorisation (multiple valorisation, optimal use of the functions of the natural heritage and the cultural-historical and new researches regarding the enrichment of their heritage attributes), in order to allow the sustainable development and their correlations with the spatial planning $[3,6,7,8]$.

According to the current directives, existing worldwide, the methodology of scientific investigation in the field impose an inter- and multidisciplinary approach that requires artistic, scientific, technical and technological competences $[9,10,11,12]$. With this approach, the composition of the working team has expanded over time and has become increasingly complex, adapting to the latest innovations in the related fields. Thus, more and more frequently, in the process of expertizing the state of conservation of cultural heritage assets and those of nature (local, national or global), the new technological discoveries regarding the instrumental analysis techniques and new methodological systems of analysis are called for processing/operation. One of the recent achievements involved in such expertise is based on the Geographic Information System (GIS). These are among the most innovative technologies that allow the geographical and cartographic representation of the features contained in relational databases, making it possible to visualize the distribution of historical monuments and protected areas in the study areas.

In recent years, this technology has been the basis of the elaboration of several important national programs in many European countries (Austria, 
Czech Republic, Germany, Italy, Spain, Slovak Republic, Great Britain, etc.) and non-European ones (Cyprus, Iraq, Japan, Kazakhstan, Morocco, Russia, Syria, Turkey, etc.) that had in mind the collection, processing, verification and centralization of the data needed for the management of protected areas and the conservation of cultural-historical assets. In Romania there have been several such projects, but the most important was carried out between 20062013, the National Program eGISpat, and it was aimed at developing a geographical information

\section{EXPERMENTAL PART}

We have started our study by doing an inventory of the orthodox churches from Iaşi counties and creating a data base with those that are ranked and included in the List of Historical Monuments updated in 2015 by the National Heritage Institute [14] according to the Law no. 422/2001 on the protection of historical monuments, republished, and to the methodological standards provided in Order no. 2260 of 18 April 2008 approving the Methodological Norms for classification and inventory of historical monuments issued by the Ministry of Culture. Then, we made a spatial data base including all ranked churches located in the county Iasi.

\section{Materials and methods}

The spatial data containing the boundaries of protected areas have been downloaded from the Ministry of Environment, Water and Forestry (Romania) and the heritage data is collected by our team. First we made an inventory of the buildings of worship based on official documents and field visits, then using the GIS software Mips 7.2 we created a spatial data base that includes all ecclesiastical buildings from the city and from the county

This vector layer has attached a table of attributes that characterize the ecclesial building, such as: monument or not, national code, year or period of construction, the interventions carried out over time on the building or on the internal or external painting, the current state of conservation etc. [3]

After the data collection we have started to analize system (GIS) for the protection of the national cultural heritage (archaeological sites and historical monuments). Within this project, complex databases have been created to record the immobile national heritage required in their management process [13].

The paper presents a mode of operation involving GIS systems in monitoring the evolution of the impact of endogenous and exogenous factors on the protected areas in the Iasi area, which includes a historical monument, which is on the National List of the Ministry of Culture.

data in correlation with other factors, as landforms, Green arear, roads etc.

\section{Study area}

Iasi County is located in the North-East of Romania on a plain between the Siret River and Prut River, from north to south being crossed by Bahlui and Jijia rivers. It is composed of four cities (Iasi, Pascani, Tg. Frumos and Harlau) and 398 villages, organized on 93 communes. Called the city of the seven hills, Iasi is the largest city in eastern Romania and the seat of Iași County with an area of $93.62 \mathrm{~km} 2$ and a population of $309.631[15,16,17]$.

\section{Data collection}

Our study has begun with making an inventory of the buildings of worship and protected areas from Iaşi metropolitan area to create a spatial data base using GIS. Many of these were ranked according to the Law no. 422/2001 on the protection of historical monuments, republished, and to the methodological standards provided in Order no. 2260 of 18 April 2008 approving the Methodological Norms for classification and inventory of historical monuments issued by the Ministry of Culture. Using GIS software TNTMips 7.2 we made a spatial data base including all ecclesiastical buildings from the city (Figure 1). This vector layer has attached a table with chracteristics from old churches such as: the national code of the monument, year or period of construction, the builder, the architectural style, the architect, the interventions carried out over time on the building, the current state of conservation etc. $[18,19,20]$. 


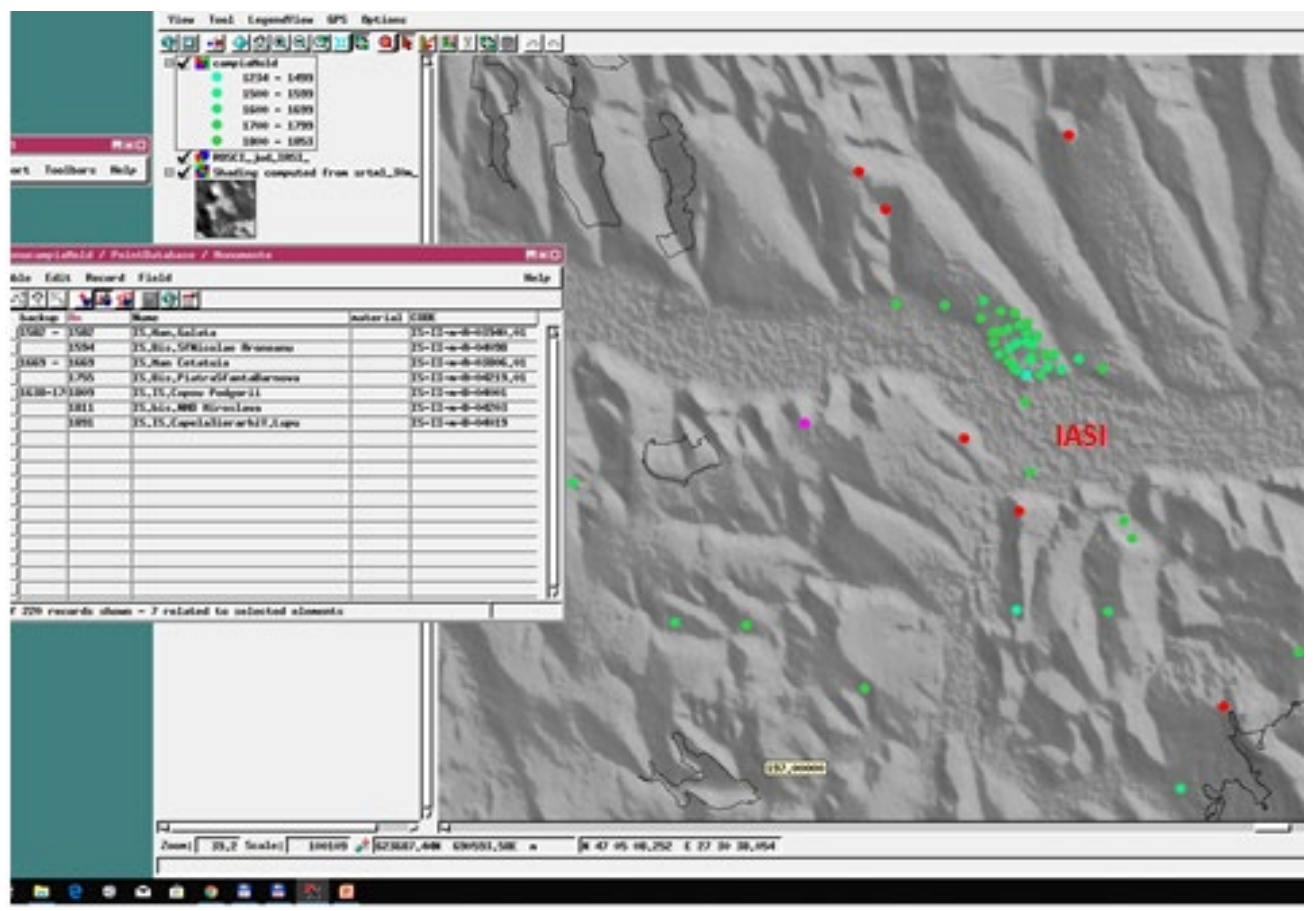

Figure 1. GIS database.

\section{RESULTS AND DISCUSSIONS}

The areas included in the Natura 2000 Network are areas with a special protection regime, which means that economic activities that do not endanger the existing plant and animal species are allowed. These areas are of two types: Special Bird Protection Areas (SPA), declared for bird species, based on the Birds Directive, and Sites of Community Importance (SCI), declared for habitats and for wild species of plants and animals, based on the Habitats Directive. Each Member State is required to submit to the Commission the National List of Sites of Community Importance (SCI). The list must be consistent with the types of habitats covered by the Habitats Directive. In Moldova the percentage of protected areas was very low before 1989 , accounting for about $1 \%$. Since the 1990 s, the number of protected areas has increased through the designation of new national and natural parks, a Biosphere Reserve (Danube Delta) and the habitat or species management area. With the admission to European Community, the number of protected areas has increased strongly by designating SCI and SPA, establishing the Natura 2000 network. Establishment of the Natura 2000 network determine increasing of surface area, and their spatial distribution has become fairly balanced across the region. However, we consider that there are still many areas that are qualifying for designate as Natura 2000 sites (Figure 2), due to presence of habitats and the species that have a communitary importance, especially for wetlands [21].

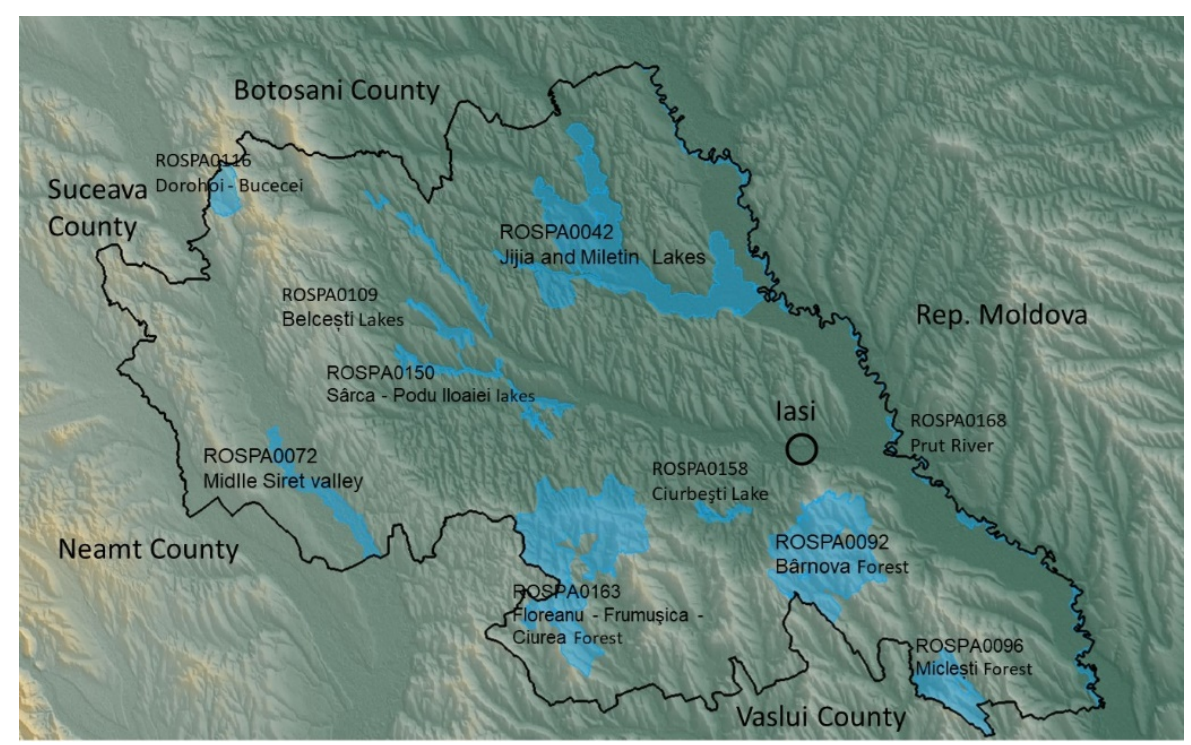

Figure 2. Natura 2000 SPA sites in Iasi County, Romania. 
In Iasi County there are 10 SPA sites distributed all over the territory. Six of them are near the rivers or wetland environment with the purpose to protect water birds, an the other four are overlapping the biggest forest are of the county in order to protect the forest birds. The most important from the diversity point of view is ROSPA0042 Eleșteele Jijiei și Miletinului that is like a little Delta of the Moldavia, having here almost all the species of birds that we can find in the Danube Delta, with few exceptions, like the Pelicans.

Each Natura 2000 site should have approved a Management plan that monitorizes the species and habitat status, the presence and abundance of species and them distribution within the site. Also these plans evaluate the pressures and threats of the human activities on the protected areas and regulate the economic activities in the site. Tourism is also a menace and an opportunity for SPA and SCI, it is a threat in those areas where tourism is very intensive and it be an opportunity in the remote areas, with little economic diversity. Integrating tourism and monument can becam an opportunity even for the monuments. So we can say that Environmental protection, Tourism and Monuments can benefit one from the other, creating a win-win situation.

Usually, for the integrity of a historical monument through time it is better to be closer to the human communities rather than isolated, except for the monasteries, that have different status and economic power.If we look at the distribution of religious monuments in Iasi city and at the number of interventions (reparations, restorations, we can observe that the closer you are to the city center, the higher the chance to receive attention from the authorities (Figure 3). In the same time being in the center means that the reason of the monument degradation is more numerous (war, vandalism, change in religious practice, change of political rulers etc).

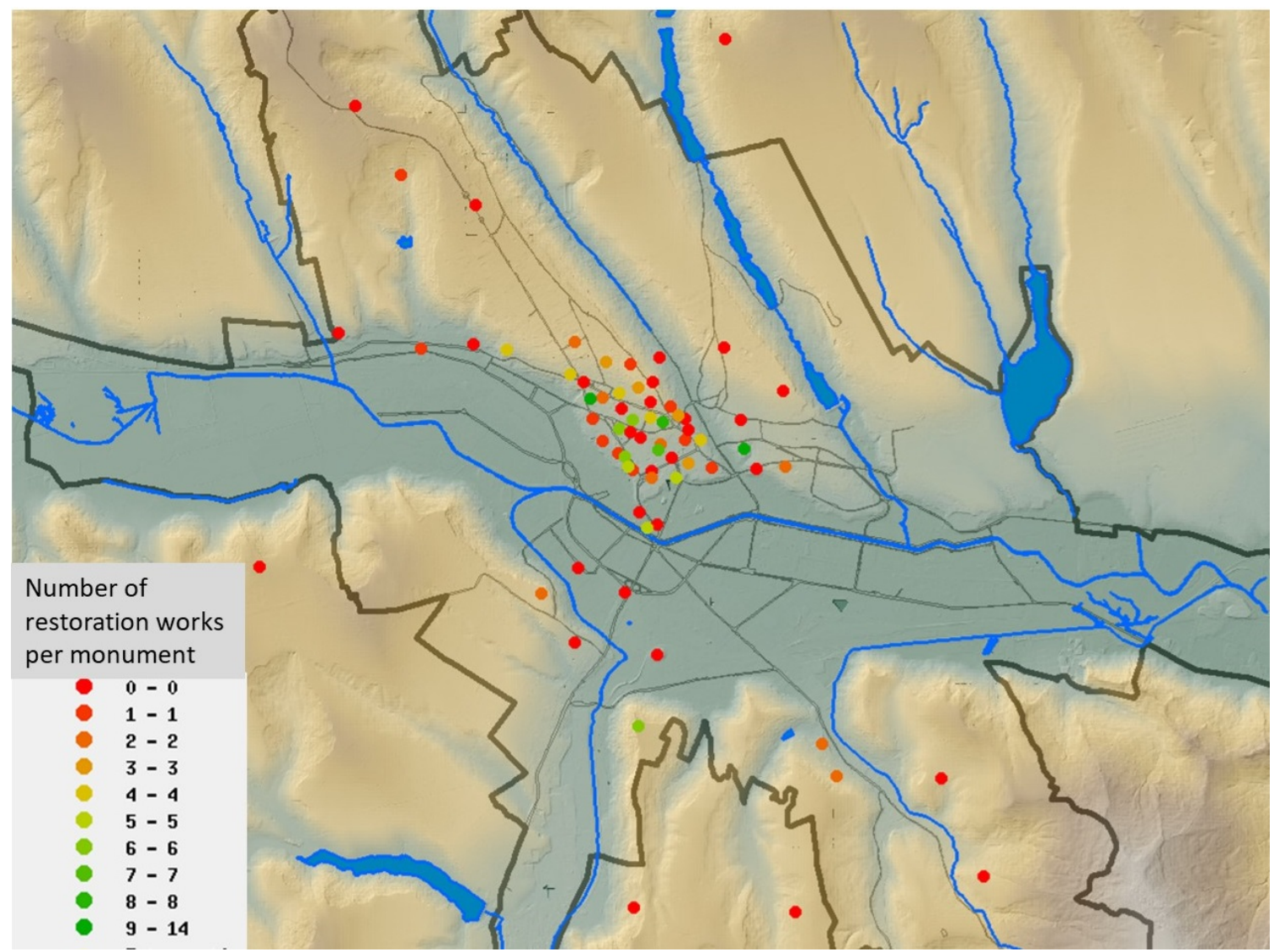

Figure 3. Number of restorations works per religious monument, in Iasi City.

Having some places that seem remote, on a local scale, even if they at a core of the communities bring some advantages sometime: for example Cetatuia Monastery, Galata Monastery or Frumoasa Monastery (Figure 4a), Podgoria Copou Monastery is surrounded by a green area buffer zone that is a Park, a Forest or even Botanichal Garden (Figure $4 \mathrm{~b})$. In this way these monuments are also into the city and at the same time "outside" and this combination prove to be good for monument conservation status. If being isolated was a problem for some monuments along the history, now with the new management plans for Natura 2000 sites, that want to diversify the sustainable economic activities in the protected areas, by promoting ecotourism this monuments may have a chance (Figure 5). 


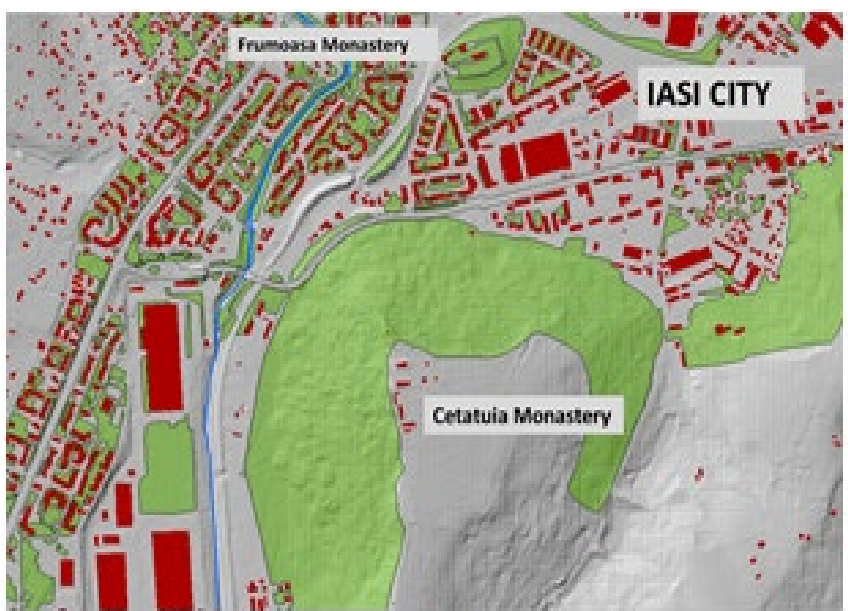

a.

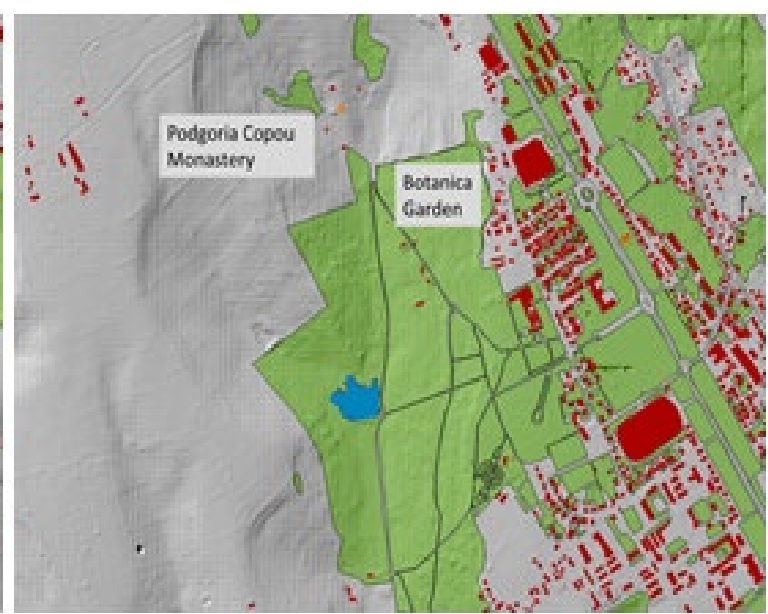

b.

Figure 4. The areas with some of the monuments in Iasi framed in protected areas: a. Cetatuia Monastery, Galata Monastery and Frumoasa Monastery; b. Podgoria Copou Monastery and Botanichal Garden.

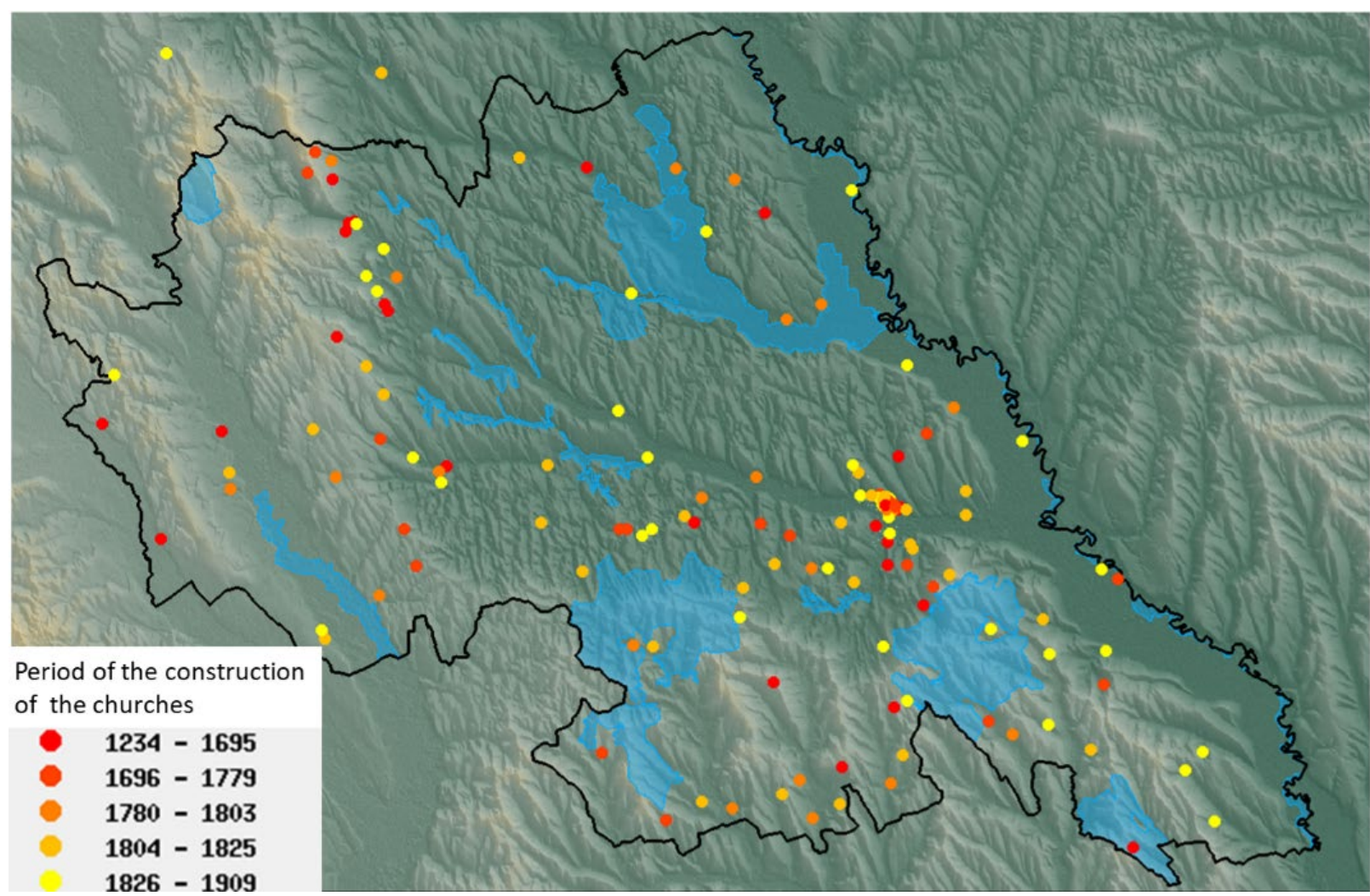

Figure 5. Religious Monuments and Natura 2000 sites SPA in Iasi County, Romania.

If we analyze the distribution of the religious monument in relation with the SPA sites in Iasi County we will observe that three sites: ROSPA0092 Pădurea Bârnova, ROSPA0042 Eleșteele Jijiei și Miletinului si ROSPA0163 Pădurea Floreanu - Frumuşica - Ciurea have important religious monument in and around the area. Also these three areas have some touristic activities, so a better cooperation between the custodies of the SPA sites and the Monument Commission can improve also the attractiveness of the sites and the conservation of the monuments (Figures 6 and 7). 


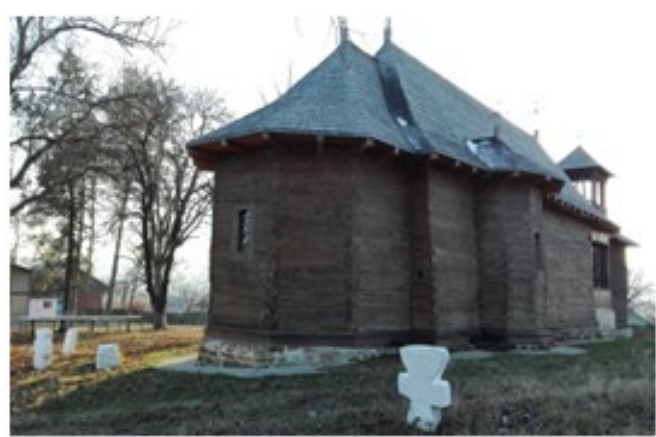

Sf. Pantelimon Church, Dobrovat

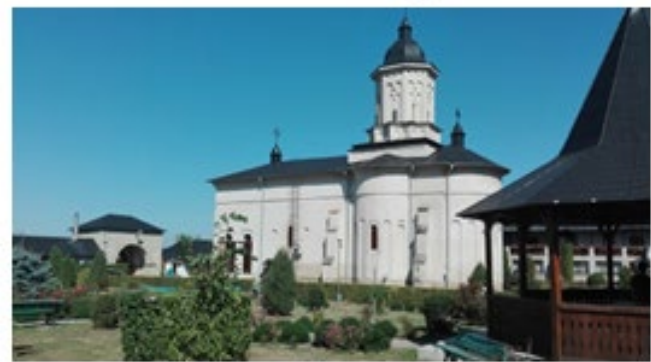

Hlincea Monastery

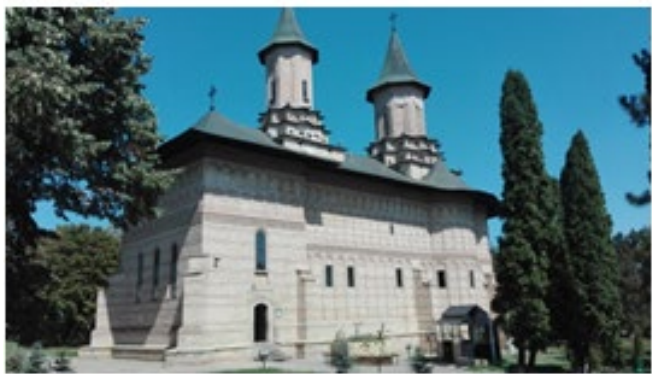

Galata Monastery



Dobrovat Monastery

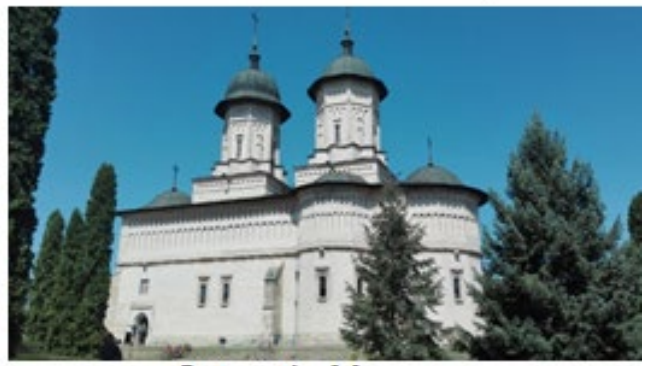

Cetatutia Monastery

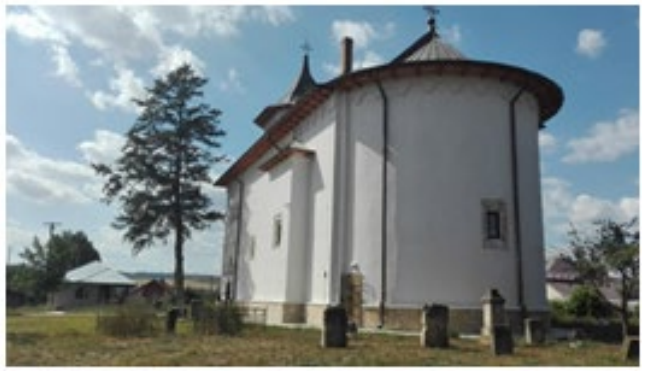

Scanteia Chruch

Figure 6. Religious monuments from the Barnova Forest surounding area.

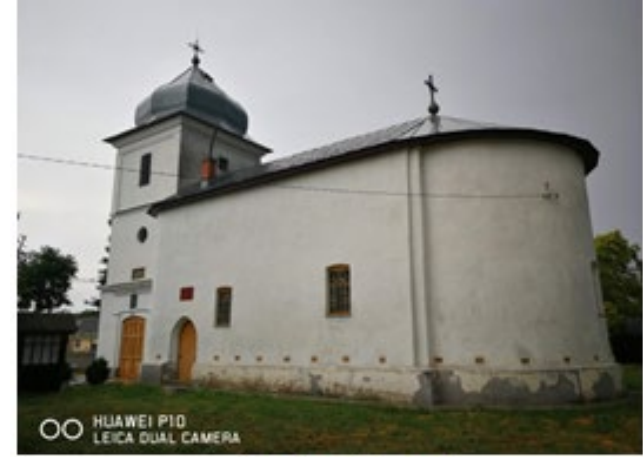

Sipote Church

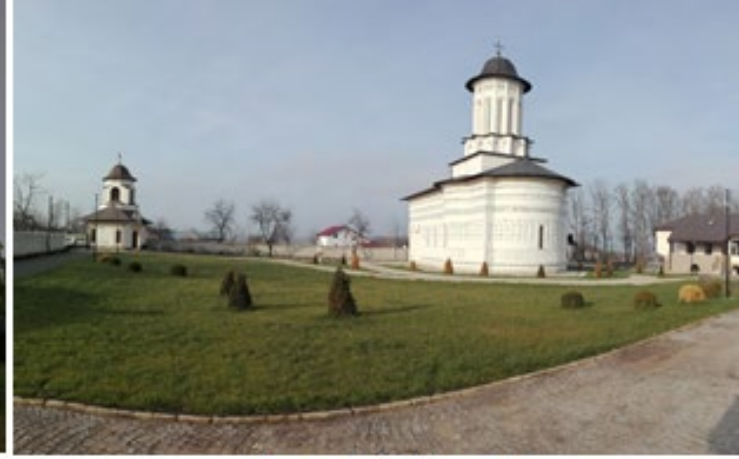

Aroneanu Church

Figure 7. Religious monument from Elesteele Jijiei si Miletinului SPA.

\section{CONCLUSIONS}

Using GIS in this study, a series of important information on protected areas, including historical monuments in the Iasi area, was identified, correlated and analyzed, such as:

- visual representation of the geographical and cartographic distribution of the protected areas, respectively of the historical monuments;

- highlighting the evolution of the distribution of protected areas and historical monuments; Also, based on the information gathered, tourist routes can be established, which highlight certain characteristics of the monuments (for example, the route of the monuments delimited at the level of the old urban nucleus and those that were most recently restored).

Of course, the database created for the areas and monuments under study is much larger taking into account other important features, which highlight the current state of preservation of the monuments and especially the monuments in critical condition of pre-collapse and which must be immediately intervened. 
Being a live GIS system, it provides information in a database that can be easily updated and helps identify critical or risk situations that require urgent intervention.Out of all the protected areas and historical monuments in Iasi County, only 20\% have tourist potential or can become a point of attraction, connected with other natural or artificial tourist attractions in the area. Commonly maintained by community members over the course of hundreds of years, and recently introduced to national lists of rehabilitated nature assets and those of financially restored monuments from various sources, these areas and monuments can be transformed from generating objectives. from reliable sources of income, if they are included in a tourist circuit that will enhance or exploit their functions optimally.

\section{ACKNOWLEDGEMENT}

This work was supported by a grant of the Romanian Ministery of Research and Innovation, CCCDI UEFISCDI, project number PN-III-P1-1.2 - PCCDI-2017-0239/60PCCDI 2018, within PNCDI III.

\section{REFERENCES}

[1] Conservation Management Partnership: Proposed Clasification of Direct Threats, October 2007; http://fosonline.org/CMP/IUCN/browse.cfm?TaxID=DirectThreats

[2] Stingu (Palici), C.C., Nedeff, V., Mosnegutu, E.F., Sandu, I., Kostrakiewicz-Gierałt, K., Vasilache, V., Antonovici (Munteanu), Date privind ariile protejate din județul Iași din perspectiva normelor europene, EUROINVENT International Workshop, Scientific, Technological and Innovative Research in Current European Context, 11th edition, 16 May 2019, Iasi, Topics: Scientific Inquiries through Elective Elaborations, (Editors: I.G. Sandu, I. Sandu, I.C. Negru and A.S. Ciornei), Ed. PIM, 2019, pp. 185-210;

[3] Stingu (Palici), C.C., Nedeff, V., Sandu, I., Kostrakiewicz-Gierałt, K., Vasilache, V., Antonovici (Munteanu), M.O., Rolul și funcțiile ariilor protejate în contextul actual geopolitic european, EUROINVENT - International Workshop, Scientific, Technological and Innovative Research in Current European Context, 11 th edition, 16 May 2019, Iasi, Topics: Scientific Inquiries through Elective Elaborations, (Editors: I.G. Sandu, I. Sandu, I.C. Negru and A.S. Ciornei), Ed. PIM, 2019, pp. 227-236;

[4] Government Emergency Ordinance No. 57/2007, privind regimul ariilor naturale protejate, conservarea habitatelor naturale, a florei şi faunei sălbatice, Government of Romania, 2007;

[5] Spiridon, P., Contributions on integrated scientific conservation of cultural heritage, PhD Thesis, Alexandru Ioan Cuza University of Iasi, 2017;

[6] Sandu, I., Branzila, M., Sandu, I.G., Scientific Conservation of the Stone Monuments, Al.I.Cuza University Publishing House, Iasi, 2009;

[7] Sandu, I., Degradation and Deterioration of the Cultural Heritage, Vol. I and II, Al.I.Cuza University Publishing House, Iasi, 2008;

[8] Sandu, I.C.A., Sandu, I., Popoiu, P., Van Saanen, A., Methodological Aspects Concerning Scientific Conservation of the Cultural Heritage, Ed. Corson, Iasi, 2001;

[9] Sandu, I., Sandu, I.C.A., Van Saanen, A., Scientific Expertize of the Art Works, vol I, Al.I.Cuza University Publishing House Iasi, 1998;

[10] Berca, M., Teoria gestiunii mediului și a resurselor naturale, Ed. Grand, Bucuresti, 1998;

[11] Blake, J., Overcoming the value - action gap in environmental policy: tensions between national policy and local experience, Local Environment, 4(3), 1999, pp.257-278;

[12] Carr, S., Tait, J., Differences in the attitudes of farmers and conservationists and their implications, Journal of Environmental Management, 32(2), 1991, pp. 281-294;

[13] Petrescu, F., The use of GIS technology in Cultural Heritage, Proceedings of the XXI International CIPA Symposium, Greece, 2007; [http://cipa.icomos.org/fileadmin/template/doc/ATHENS/FP114.pdf].

[14] Institutul Naţional al Patrimoniului, Lista Monumentelor Istorice 2015, Judeţul Iaşi.

[15] Spiridon, P., Ursu, A., Sandu, I., Heritage Management Using Gis, Informatics, Geoinformatics and Remont Sensing, Vol. III, Cartigaphy and GIS, Book 2 Series: International Multidisciplinary Scientific GeoConferenceSGEM 2016, 2016, pp. 262-270, DOI: 105593/sgem2016B23; 
[16] Spiridon, P., Ursu, A., Sandu, I., Touristic Revaluation of the Cultural Heritage in the Moldavian Plain, Nano, Bio and Green - Tchnologies for a Sustainable Future, Vol. II, Green Buildings Technologies and Materials. Green Design and Sustainable Architecture, Book 6 Series: International Multidisciplinary Scientific GeoConferenceSGEM 2016, 2016, pp. 381-388, DOI: 105593/sgem2016B62;

[17] Ursu, A., Spiridon Ursu, P., Rusu, A., Sandu, I., Heritage Sites at Risk in Moldavian Plain - Romania, Using G.I.S, Informatics, Geoinformatics and Remont Sensing, Vol. III, Cartigaphy and GIS, Book 2 Series: International Multidisciplinary Scientific GeoConference-SGEM19(2.2), 2019, pp. 879-886, DOI: 105593/sgem2016B231;

[18] Sandu, I., Sandu I.C.A., New Interdisciplinary Aspects on Science for Conservation of Cultural Heritage (II), Egyptean Journal of Archaeologycal and Restoration Studies, 3(2) 2013, pp. 73-83;

[19] Spiridon, P., Sandu, I., Conservation of the Cultural Heritage: From participation to collaboration, ENCATC Journal of Cultural Management \& Policy, 2015(5), pp. 43-53;

[20] Institutul Naţional al Patrimoniului, eGISpat - baza de date spațială; (http://patrimoniu.gov.ro/ro/monumenteistorice/egispat)

[21] Ion, C., Stoleriu, C.C., Baltag, E., Mânzu, C., Ursu, A., Ignat, A.E. 2011, Păsările şi habitatele din zonele umede ale Moldovei, Ed. Alexandru Ioan Cuza University of Iaşi, 247p. 